Jurnal Perikanan (2020) Volume 10. No. $1: 55-69$

DOI : https://doi.org/10.29303/jp.v10i1.175

\title{
PROFIL DARAH IKAN KAKAP PUTIH YANG DIINFEKSI BAKTERI Vibrio sp. DENGAN PEMBERIAN LIDAH BUAYA (Aloe Vera)
}

\section{PROFILE OF BLOOD OF SEABASS INFECTED BY Vibrio sp. WITH THE ADDITION OF ALOE VERA EXTRACT}

\author{
Novita $^{1 *)}$, Dewi Nur'aeni Setyowati ${ }^{1)}$, Baiq Hilda Astriana ${ }^{2)}$ \\ ${ }^{1)}$ Program Studi Budidaya Perairan Universitas Mataram \\ ${ }^{2)}$ Program Studi Ilmu Kelautan Universitas Mataram \\ *)alamat korespondensi : novitajohan05@gmai.com
}

\begin{abstract}
Abstrak
Ikan kakap putih (Lates calcarifer Bloch) merupakan salah satu jenis ikan konsumsi yang cukup populer di Indonesia.. Salah satu kendala yang dihadapi dalam usaha budidaya ikan kakap putih yaitu adanya serangan penyakit. Salah satu penyakit yang menyerang ikan air laut adalah bakteri Vibrio harveyi. Lidah buaya mengandung beberapa bahan therapeutic penting. Tujuan penelitian untuk mengetahui efektivitas penambahan ekstrak lidah buaya (Aloe vera) dalam pakan terhadap penambahan total sel darah merah, sel darah putih, kadar hemoglobin, diferensial leukosit dan tingkat kelangsungan hidup ikan kakap putih dan untuk mengetahui dosis ekstak lidah buaya (Aloe vera) yang paling baik. Penelitian ini menggunakan Rancangan Acak Lengkap (RAL) yang terdiri dari 6 perlakuan dan 3 kali ulangan sehingga memperoleh 18 unit percobaan. Perlakuan P0: $0 \mathrm{ml}$ ekstrak $/ 500 \mathrm{~g}$ pakan, P1: $10 \mathrm{ml}$ ekstrak $/ 500 \mathrm{~g}$ pakan, P2: $20 \mathrm{ml}$ ekstrak /500 g pakan, P3: $40 \mathrm{ml}$ ekstrak /500 g pakan, P4: $60 \mathrm{ml}$ ekstrak /500 g pakan, P5: $100 \mathrm{ml}$ ekstrak /500 g pakan.Data hasil pengamatan sel darah putih, sel darah merah, diferensial leukosit serta tingkat kelangsungan hidup diuji menggunakan Analysis of Variance (ANOVA) dan jika berbeda nyata dilanjutkan dengan uji Tukey pada taraf nyata 5\%.Hasil penelitian menunjukkan bahwa semua perlakuan memberikan pengaruh yang tidak berbeda nyata $(\mathrm{p}<0.05)$ terhadap jumlah eritrosit, kadar hemoglobin, leukosit, sel limfosit, sel neutrofil, tetapi memberikan pengaruh yang berbeda nyata terhadap jumlah leukosit, jumlah monosit dan tingkat kealngsungan hidup ikan kakap putih.
\end{abstract}

Kata kunci: Ikan kakap putih, bakteri, lidah buaya (Aloe vera), leukosit, monosit dan tingkat kelangsungan hidup.

\begin{abstract}
Seabass (Lates calcarifer Bloch) is a type of consumption fish that is quite popular in Indonesia. One of the obstacles faced in the cultivation of white snapper is
\end{abstract}


Jurnal Perikanan (2020) Volume 10. No. $1: 55-69$

DOI : https://doi.org/10.29303/jp.v10i1.175

the presence of disease. One of the diseases that attack seawater is Vibrio harveyi. Aloe vera contains several important therapeutic ingredients. The purpose of this study was to determine the effectiveness of the addition of aloe vera extract (Aloe vera) in feed to the addition of total red blood cells, white blood cells, hemoglobin levels, differential leukocytes and survival rate of white snapper and to determine the extra dose of aloe vera (Aloe vera) which the best. This study used a Completely Randomized Design (CRD) consisting of 6 treatments and 3 replications to obtain 18 experimental units. Treatment P0: $0 \mathrm{ml}$ extract / $500 \mathrm{~g}$ feed, P1: $10 \mathrm{ml}$ extract / $500 \mathrm{~g}$ feed, P2: $20 \mathrm{ml}$ extract / $500 \mathrm{~g}$ feed, P3: $40 \mathrm{ml}$ extract / $500 \mathrm{~g}$ feed, P4: $60 \mathrm{ml}$ extract / $500 \mathrm{~g}$ feed , P5: $100 \mathrm{ml}$ extract / $500 \mathrm{~g}$ feed. Data from observations of white blood cells, red blood cells, differential leukocytes and survival rates were tested using Analysis of Variance (ANOVA) and if significantly different continued with Tukey's test at $5 \%$ significance level. The results showed that all treatments had a non-significant effect $(\mathrm{p}<0.05)$ on the number of erythrocytes, hemoglobin levels, leukocytes, lymphocyte cells, neutrophil cells, but had a significantly different effect on the number of leukocytes, the number of monocytes and the level of survival of seabass

Keywords: seabass, bacteria, aloe vera, leukocytes, monocytes and survival rate.

\section{PENDAHULUAN}

Ikan kakap putih (Lates calcariferBloch) atau seabass merupakan salah satu jenis ikan konsumsi yang cukup populer di Indonesia, ikan kakap putih memiliki kandungan protein yang sangat tinggi.Oleh karena itu keberadaan dan perkembangan ikan kakap putih mulai ditingkatkan karena pertumbuhanya relatif lebih cepat dan mudah meneyesuaikan diri dengan lingkungannya.Ikan kakap putih merupakan ikan yang luwes yaitu jenis ikan yang dapat hidup di air laut, payau dan air laut.Hal inilah yang membuat ikan kakap putih sangat mudah dibudidayakan serta metode pemeliharaan yang relatif mudah karena ikan kakap putih dapat menyesuaikan diri pada kondisi lingkungan.

Salah satu kendala yang dihadapi dalam usaha budidaya dan produksi benih ikan kakap putih sering menghadapi masalah yaitu adanya serangan penyakit. Wabah penyakit pada kegiatan budidaya dipengaruhi oleh interaksi yang tidak seimbang antara ikan, lingkungan, dan patogen (Austin \& Austin, 2012).Saat fase benih, ikan kakap mudah stres sehingga pertahanan tubuh ikan mengalami penurunan. Stres diakibatkan kondisi lingkungan yang memburuk serta ditunjang oleh keberadaan patogen seperti bakteri, jamur, parasit, dan virus, sehingga penyakit akan mudah menginfeksi ikan (Affandi \& Tang 2002).

Secara ekonomis masalah penyakit pada ikan dapat merugikan usaha budidaya, menurunkan produksi dan kualitas air dan bahkan dapat menyebabkan kematian massal.Salah satu penyakit yang menyerang ikan air laut adalah bakteri Vibrio harfeyi.Bakteri Vibrio merupakan genus yang dominan pada lingkungan air payau dan air laut.Bakteri Vibrio menyerang lebih dari 40 spesies ikan di 16 negara.Vibrio sp.merupakan bakteri gram negatif, sel tunggal berbentuk batang pendek dan bengkok (koma) atau lurus berukuran panjang 1,4-5,0 nm dan lebar 0,3-1,3 nm 
motil dan memiliki flagella polar. Hewan laut yang terinfeksi Vibrio khususnya pada udang dan ikan akan mengalami kondisi tubuh lemah, berenang lambat, nafsu makan hilang dan badan mempunyai bercak merah- merah.

Salah satu alternatif yang dapat digunakan untuk mengendalikan penyakit ini adalah dengan pemberian imunostimulan.Imunostimulan

merupakan suatu materi biologis atau zat sintetis yang dapat meningkatkan pertahanan non spesifik serta merangsang organ pembentuk antibodi dalam tubuh untuk bekerja secara maksimal (Ellis, 1988).Imunostimulan merupakan suatu substansi yang mempunyai kemampuan untuk meningkatkan perlawanan terhadap infeksi penyakit terutama oleh sistem fagositik.Penggunaan imunostimulan dalam terapi kadangkala mengalami hambatan.Hambatan yang sering muncul adalah karena imunostimulan yang tersedia di pasaran merupakan obat paten yang mayoritas diimpor dari luar negeri.

Selain itu lidah buaya merupakan bahan herbal yang dapat meningkatkan sistem kekebalan tubuh dan tidak menimbulkan residu pada ikan adalah lidah buaya (Aloe vera).Ekstrak lidah buaya mempunyai kandungan zat aktif yang sudah teridentifikasi seperti Saponin, Sterol, Acemannan (Purbaya, 2003 dalam Arianti et al., 2012).Acemannandiketahui berfungsi sebagai imunostimulator yang meningkatkan respon imun sebagai pertahanan terhadap patogen intraseluler seperti virus, bakteri dan parasit yang berfungsi sebagai antibiotik.Sedangkan Menurut Jatnika dan Saptoningsih (2009), lidah buaya mampu menstimulasi kekebalan tubuh.Hal ini dikarenakan lidah buaya mengandung senyawa aktif flavonoid yang mampu mengaktifkan sel imun (Wahyuningrum et al., 2013 dalamKamaluddin, 2011).

Penelitian serupa pernah dilakukan oleh Prasetio (2017) menggunakan serbuk lidah buaya dengan dosis yang berbeda pada ikan jelawat yang diuji tantang menggunakan bakteri Aeromonas hydrophila, menunjukkan perubahan bobot ikan jelawat terbaik pada perlakuan serbuk lidah buaya 40 ppt dengan nilai 1,77 gram, dan kelangsungan hidup sebesar $93,33 \%$. Sedangkan penelitian tentang profil darah ikan kakap putih yang diinfeksi bakteri Vibrio sp. dengan penambahan ekstrak lidah buaya (Aloe vera) dengan dosis yang lebih tinggi belum pernah dilakukan sebelumnya.

Oleh karena itu, penelitian ini dilakukan untuk mengetahui efektivitas penambahan ekstrak lidah buaya dalam pakan terhadap penambahan total sel darah merah, sel darah putih, kadar hemoglobin, diferensial leukosit, dan tingkat kelangsungan hidup ikan kakap putih, dan mengetahui dosis paling baik terhadap penambahan total sel darah merah, sel darah putih, kadar hemoglobin, diferensial leukosit, dan tingkat kelangsungan hidup ikan kakap putih.

\section{METODE PENELITIAN Waktu dan Tempat}

Penelitian ini dilaksanakan pada tanggal 15 Juni sampai dengan 10 Juli 2019, yang bertempat di Balai PerikananBudidaya Laut Sekotong Lombok Barat, Nusa Tenggara Barat.

\section{Rancangan Percobaan}

Penelitian ini dilakukan dengan metode eksperimental menggunakan Rancangan Acak Lengkap (RAL).Rancangan penelitian 
menggunakan 6 dosis perlakuan dan 3 ulangan yaitu: $\mathrm{P} 0: 0 \mathrm{ml}$ ekstrak $/ 500 \mathrm{~g}$ pakan,P1: $10 \mathrm{ml}$ ekstrak /500 g pakan, $\mathrm{P} 2$ : 20 mlekstrak $/ 500$ g pakan, P3: $40 \mathrm{ml}$ ekstrak /500 g pakan, P4: 60 mlekstrak 1500 g pakan,P5: 100 mlekstrak /500 g pakan.

\section{Prosedur Penelitian}

Langkah-langkah yang dilakukan dalam pelaksanaan penelitian adalah tahap persiapan kontainer, pembuatan ekstrak lidah buaya, penumbuhan bakteri Vibrio sp., pencampuran ekstrak lidah buaya ke dalam pakan, persiapan ikan uji, pengambilan sampel darah, uji tantang dengan bakteri Vibrio sp., perhitungan total sel darah putih, perhitungan total sel darah merah, perhitungan kadar hemoglobin, perhitungan diferensial leukosit, perhitungan tingkat kelangsungan hidup, kualitas air.

\section{Tahap Persiapan kontainer}

Kontainer dengan volume 40 liter dicuci dengan sabun kemudian dibilas sampai bersih dan dikeringkan. Kontainer disusun sesuai denah rancangan perlakuan (Gambar 6).Setelah kontainer bersih dan kering kemudian dipasang selang aerasi dan batu aerasi pada masing-masing kontainer lalu diisi air laut sebanyak 30 liter.

\section{Pembuatan Ekstrak Lidah Buaya}

Ekstrak lidah buaya dibuat sesuai dengan metode Sari et al. (2012). Lidah buaya dicuci bersih, kemudian diiris tipistipis dan dioven dan selanjutnya dijemur lagi dibawah sinar matahari selama 1-3 hari sampai kering. Kemudian lidah buaya dihaluskan dan dicampur dengan $800 \mathrm{ml}$ etanol $70 \%$, kemudian disaring dan dibuang ampas lidah buaya, setelah itu dievaporasi dalam suhu $70^{\circ} \mathrm{C}$ selama
24 jam, baru didapatkan ekstrak kental dari lidah buaya.

\section{Penumbuhan Bakteri Vibrio sp.}

Bakteri Vibrio murni didapatkan di Balai Besar Perikanan Budidaya Air Payau Jepara yang kemudian ditumbuhkan kembali pada media Tripticase Soy Agar (TSA). Media TSA ditimbang terlebih dahulu sebanyak 4 gram dengan $100 \mathrm{ml}$ air.Kemudian cawan petri yang digunakan untuk menumbuhkan bakteri disterilkan menggunakan autoklaf dengan suhu $121^{\circ} \mathrm{C}$ selama 30 menit.Isolat bakteri dari laboratorium yang diremajakan pada media TSAdisimpan selama 48 jam dengan suhu $26^{\circ} \mathrm{C}$ (Husni, 2006).

\section{Pencampuran Ekstrak Lidah BuayaKedalam Pakan}

Pencampuran larutan ekstrak lidah buaya dengan pakan diawali dengan ditimbangnya larutan lidah buaya sesuai dengan dosis yang diperlukan: Perlakuan P0: $0 \mathrm{ml}$ ekstrak /500 g pakan, P1: 10 mlekstrak $/ 500$ g pakan, P2: $20 \mathrm{ml}$ ekstrak/500 g pakan, P3: $40 \mathrm{ml}$ ekstrak /500 g pakan, P4: $60 \mathrm{ml}$ ekstrak /500 g pakan, P5: $100 \mathrm{ml}$ ekstrak /500 g pakan. Langkah selanjutnya ekstrak lidah buaya yang telah diambil sesuai dosis dicampurkan langsung dengan pakan. Setelah itu pakan yang sudah ditimbang sesuai kebutuhan untuk masing masing perlakuan dimasukkan ke dalam wadah.Pakan yang telah tercampur merata dengan ekstrak lidah buaya selanjutnya dikeringanginkan pada suhu ruang.Pakan yang telah siap dimasukkan dalam wadah plastik dan disimpan dalam lemari pendingin hingga siap digunakan dan pencampuran dilakukan sekali sebelum uji tantang (Chyntia, 2014). Frekuensi pemberian pakan diberikan 
sebanyak 3 kali sehari, yaitu pada pukul 08.30, 12.30, 16.30 (Ekoet al., 2015 ; Rahmadiansyah et al.,2016).

\section{Persiapan Hewan Uji}

Ikan kakap putihyang digunakan adalah ikan yang berasal dari Balai Budidaya Perikanan Laut Sekotong. Ikan yang digunakan sebanyak 180 ekor dengan ukuran 3-5 cm. Ikan ditempatkan ke dalam bak kontainer terlebih dahulu agar dapat menyesuaikan diri dengan lingkungan baru. Setelah beberapa jam ikan dipindahkan ke kontainer dengan kepadatan 10 ekor/30 liter air.

\section{Penginfeksian Bakteri Vibrio sp.}

Bakteri Vibrio sp. yang diinfeksi merupakan bakteri Vibrio sp. dalam bentuk media cair yang sebelumnya diisolasi dalam laboratorium menggunakan TSA. Proses penginfeksian bakteri Vibrio sp. dilakukan dengan cara diambil bakteri menggunakan pipet tetes sebanyak $1 \mathrm{ml}$ dan bakteri dimasukkan kedalam media pemeliharaan ikan. Penginfeksian dilakukan 1 hari setelah darah ikan diambil.

\section{Pengambilan Sampel Darah Ikan}

Selama penelitian, pengambilan sampel darah dilakukan sebanyak tiga kali yaitu satu kali sebelum perlakuan dan dua kali setelah pemberian perlakuan. Pengambilan darah ikan menggunakan spuit secukupnya, kemudian dipindahkan ke tabung eppendorf lalu diambil menggunakan pipet mikro sebanyak 0,3 ml. Pengamatan pada (I) dilakukan pada hari ke-3. Pengambilan sampel darah pada awal penelitian dilakukan untuk mengetahui jumlah sel darah awalikan uji yang akan digunakan sebagai acuan ada atau tidaknya peningkatan sel darah setelah pemberian pakan yang telah ditambahkan ekstrak lidah buaya. Pengambilan sampel darah ke dua (II) dilakukan pada hari ke-10, dilakukan pengambilan sampel darah ke(III) yaitu pada hari ke17. Pengambilan sampel darah dengan selang waktu 7 hari sekali yaitu untuk mengetahui peningkatan sel darah setelah pemberian ekstrak lidah buaya (Ayu, 2013).

\section{Uji Tantang dengan Bakteri Vibrio sp.}

Ikan yang telah melalui proses adaptasi selama 2 hari selanjutnya diuji tantang. Pada saat uji tantang, setiap perlakuan diinfeksi dengan bakteri Vibrio sp. sebanyak $1 \mathrm{ml}$ dengan dosis ekstrak lidah buaya $(0 \mathrm{ml}, 10 \mathrm{ml}, 20 \mathrm{ml}, 40 \mathrm{ml}, 60$ $\mathrm{ml}, 100 \mathrm{ml}$ ). Hasil pengenceran dengan dosis $10^{6}$ sebanyak $1 \mathrm{ml}$ yang mengacu pada hasil LD 50 oleh Faridah (2010). Proses pengenceran bertingkat dilakukan sebanyak enam kali, proses ini dilakukan disekitaran bunsen. Media aquades yang belum ada bakterinya diisikan ke dalam 12 buah tabung reaksi steril sebanyak 9 ml masing-masing tabung. Diambil 1-2 ose bakteri murni yang sudah tumbuh, isikan ditabung pertama sebagai pengenceran pertama, selanjutnya dari tabung satu diambil $1 \mathrm{ml}$ diisikan ke tabung 2 dan 3. Proses ini dilakukan sebanyak 3 ulangan. Hasil akhir pengenceran ke 6 disimpan kedalam media TSA dan didiamkan selama 24 jam.

\section{Parameter Penelitian}

Parameter yang digunakan untuk menguji hasil penelitian ini yaitu perhitungan jumlah sel darah merah, jumlah sel darah putih, pengukuran kadarhemoglobindan pengukuran diferensiansileukosit, pengukuran kualitas air dan tingkat kelangsungan hidup ikan. 


\section{Total Sel Darah Putih}

Adapun rumus yang digunakan untuk menentukan total sel darah putih (Puspasari 2010dalam Ilham, 2018 ) yaitu:Jumlah leukosit yang dihitung = Jumlah leukosit $\mathrm{x}$ Faktor pengencer/Volume yang dihitung.

\section{Total Sel Darah Merah}

Adapun rumus yang digunakan untuk menentukan total sel darah merah yaitu: Jumlah eritrosit yang dihitung $=$ Jumlah eritrosit $\mathrm{x}$ Faktor pengencer/Volume yang dihitung

\section{Pengukuran Kadar Hemoglobin}

Prosedur perhitungan kadar hemoglobin dilakukan dengan mengacu pada metode Sahli yang mengkonversikan darah ke dalam bentuk asam hematin setelah darah ditambah dengan asam klorida (Dosim et al., 2013dalam Ilham, 2018).

\subsubsection{Diferensial Leukosit}

.Diferensial leukosit dihitung menggunakan rumus Rahma (2015).

Presentase Limfosit $=\frac{L}{100} \times 100 \%$

Presentase Monosit $=\frac{M}{100} \times 100 \%$

Presentase Neutrofil $=\frac{N}{100} \times 100$

\subsubsection{Tingkat Kelangsungan Hidup}

Kelangsungan hidup ikan kakap putih diamati berdasarkan rumus dari Effendi (1978) dalam Midanawati et al. (2009) sebagai berikut:

$$
\mathrm{SR}=\frac{\mathrm{Nt}}{\mathrm{N} 0} \times 100 \%
$$

Keterangan:SR $=$ Tingkat Kelangsungan Hidup, $\mathrm{N}_{\mathrm{t}}=$ Jumlah Ikan yang Hidup diakhir, $\mathrm{N}_{0}=$ Jumlah Ikan yang ditebar diawal.

\section{Analisis Data}

Data hasil pengamatan sel darah merah, sel darah putih, diferensial leukosit, serta tingkat kelangsungan hidup diuji dengan menggunakan Oneway Annova(ANOVA) dan apabila berbeda nyata maka dilanjutkan dengan uji tukey pada taraf 5\%, sedangkan data hasil pengamatan kualitas air dianalisis secara deskriptif.

\section{HASIL DAN PEMBAHASAN Eritrosit}

Berdasarkan hasil uji One-way Annova (ANOVA) diketahui bahwa penambahan ekstrak lidah buaya tidak berpengaruh secara signifikan terhadap peningkatan jumlah eritrosit yang dihasilkan $(\mathrm{P}<0,05)$. Hasil penelitian dapat dilihat pada Gambar 1.

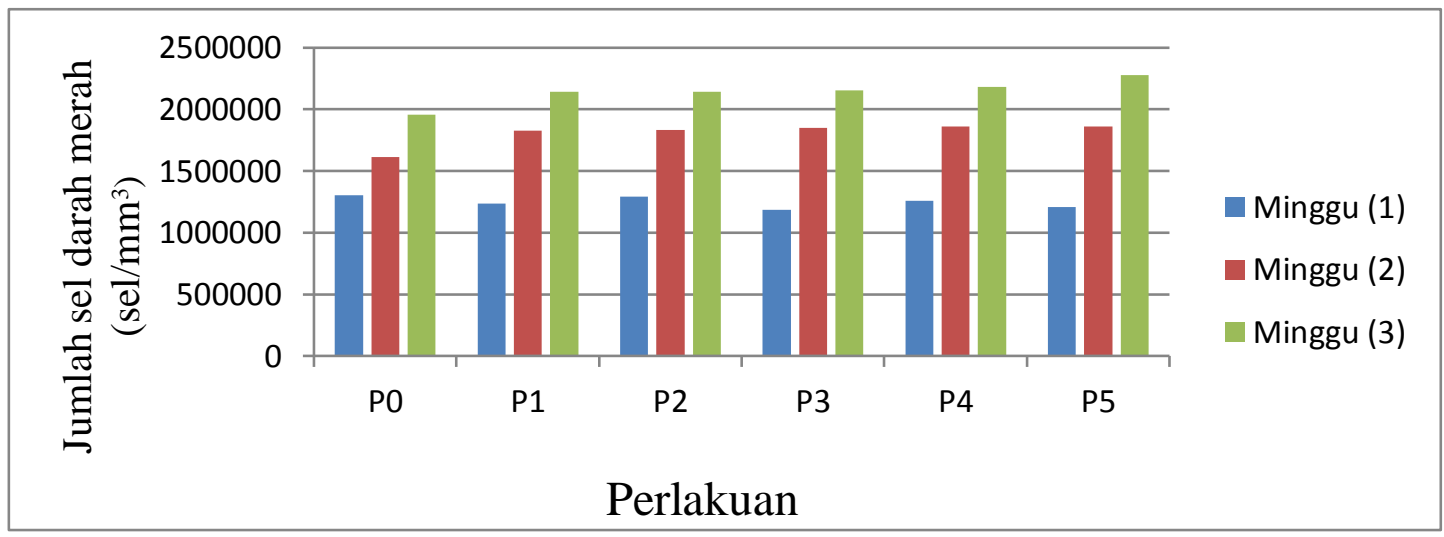


Jurnal Perikanan (2020) Volume 10. No. $1: 55-69$

DOI : https://doi.org/10.29303/jp.v10i1.175

Gambar 1. Grafik Pengamatan Total Sel Darah Merah Ikan Kakap Putih

Pengamatan jumlah eritrosit dilakukan 3 kali selama penelitian, yaitu (1) sebelum diberikan perlakuan dan sebelum diinfeksikan bakteriVibrio sp. (2) dilakukan 7 hari sesudah perlakuan dan diinfeksikan bakteri Vibrio sp. dan (3) dilakukan pada akhir penelitian. Pada pengamatan total sel darah merah, didapatkan hasil bahwa semua perlakuan menunjukkan peningkatan setelah diinfeksi dengan bakteri Vibrio sp. namun tidak menunjukkan pengaruh yang berbeda nyata antara setiap perlakuan setelah pemberian ekstrak lidah buaya. Menurut Ary (2007) dalam Dopongtanung (2008) seharusnya ikan yang terinfeksi penyakit akan mengalami penurunan jumlah sel darah merah (eritrosit)yang disebabkan karena terganggunya fungsi ginjal dan limfa yang akan memproduksi sel darah merah (eritrosit) tersebut. Hasil penelitian ini menunjukkan bahwa penginfeksian bakteriVibrio sp. dan penambahan ekstrak lidah buaya menunjukkan hasil yang bertolak belakang karena jumlah eritrosit setelah dianalisa dan dilakukan perhitungan menunjukkan kisaran eritrosit dengan jumlah total 1.301687$2.276667 \mathrm{sel} / \mathrm{mm}^{3}$, meski terjadi peningkatan, jumlah total eritrosit pada penelitian ini masih dalam kisaran normal. Hal ini sesuai dengan pernyataan Hartika (2014) yang mengatakan bahwa pada umumnya sel darah merah pada ikan yaitu berkisar antara 20.000-3.000.000 $\mathrm{sel} / \mathrm{mm}^{3}$.

\section{Leukosit}

Hasil analisis statistik uji One-way Annova pada pengamatan menunjukkan bahwa penginfeksian dengan bakteri Vibrio sp.dan pemberian ekstrak lidah buaya memberikan pengaruh yang signifikan $(\mathrm{P}<0,05)$ terhadap jumlah leukosit pada ikan kakap putih pada minggu (II) dan minggu (III). Akan tetapi tidak memberikan pengaruh yang signifikan pada minggu (I). Hasil penelitian dapat dilihat pada Gambar 2.

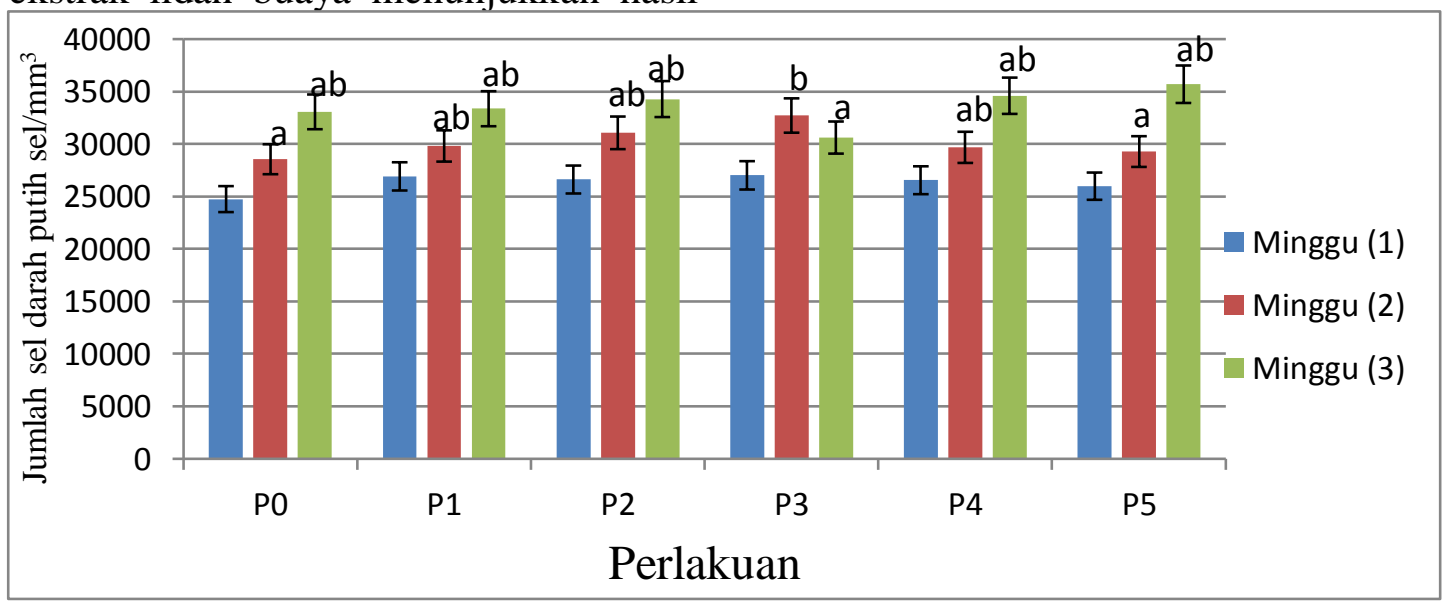

Gambar 2. Grafik Pengamatan Total Sel Darah Putih Ikan Kakap Putih

Hasil pengamatan jumlah leukosit pada ikan kakap putih yang diinfeksi bakteri Vibrio sp. dengan pemberian ekstrak lidah buaya memberikan hasil yang berbeda nyata pada minggu (II)dan mingu (III). Hasil pengamatan total 
Jurnal Perikanan (2020) Volume 10. No. 1 : 55-69

DOI : https://doi.org/10.29303/jp.v10i1.175

leukosit mengggunakan uji One-way Annova pada setiap perlakuan menunjukkan adanya peningkatan jumlah total leukosit. Pada minggu (I) jumlah leukosit tertinggi didapatkan pada perlakuan P3 dengan jumlah total leukosit $27.017 \mathrm{sel} / \mathrm{mm}^{3}$, sedangkan jumlah leukosit terendah didapatkan pada perlakuan P0 dengan jumlah total leukosit sebanyak $24.167 \mathrm{sel} / \mathrm{mm}^{3}$. Berdasarkan hasil uji lanjut Tukey pada minggu (II), perlakuan P3 menunjukkan hasil tertinggi dengan jumlah leukosit sebanyak32.067 sel $/ \mathrm{mm}^{3}$, sedangkan total leukosit terendah didapatkan pada perlakuan P0 yaitu sebanyak 28.550 $\mathrm{sel} / \mathrm{mm}^{3}$.Uji lanjut Tukey Pada minggu (III)didapatkan jumlah total leukosit tertinggi yaitu pada perlakuan P5 dengan jumlah total leukosit sebanyak $35.700 \mathrm{sel} / \mathrm{mm}^{3}$, sedangkan jumlah total leukosit terendah pada perlakuan P3 dengan kisaran nilai30.617 sel $/ \mathrm{mm}^{3}$. Jumlah leukosit selama pengamatan masih dalam kisaran normal, hal ini sesuai dengan pernyataan Rastogi (1977) dalam Sani (2014) yang menyatakan bahwa jumlah leukosit pada ikan berkisar antara 20.000-150.00 sel/ $/ \mathrm{mm}^{3}$.

Bertambahnya jumlah leukosit dikarenakan adanya pengaruh pemberian ekstrak lidah buaya, sehingga dapat dinyatakan bahwa pemberian ekstrak lidah buayaberpengaruh terhadap jumlah sel darah putih pada ikan kakap putih. Hal ini terjadi karena bahan aktif (benzenna) yang terdapat dalam lidah buaya bekerja menstimulasi dan meningkatkanproduktifitas antibodi tubuh ikan. Rendahnya kadar leukosit pada perlakuan P0 dikarenakan jumlah bahan aktif yang terdapat dalam ekstrak lidah buaya kurang optimum sehingga tingkat kesembuhan ikan pun menjadi lambat.Pada penelitian ini, penggunaan dosis ekstrak lidah buaya 100\% merupakan dosis yang masih terbilang optimum, akan tetapi belum pernah dilakukan penelitian penggunaan ekstrak yang lebih tinggi. Sehingga tidak dapat disimpulkan bahwa semakin tinggi dosis ekstrak lidah buaya yang digunakan apakah semakin baik dalam meningkatkan jumlah leukosit.

Anderson (1993), menyatakan leukosit merupakan salah satu komponen darah yang berfungsi sebagai pertahanan non spesifik yang akan melokalisasi dan mengeliminir patogen melalui fagositosis. Anderson dan Siwicki (1993) dalam Susandi (2017) menerangkan bahwa penurunan jumlah leukosit pada ikan di karenakan ikanmengalami stress ataupun adanya infeksi sehingga menunjukkan terjadinya penurunan jumlah leukosit pada darah ikan.Pernyataan yang sama juga dipaparkan oleh Ary (2007) dalam Susandi (2017) bahwa penurunan jumlah leukosit total terjadi akibat adanya respon dari tubuh ikan terhadap kondisi lingkungan, faktor stress, dan infeksi penyakit.

\section{Hemoglobin}

Hasil analisis data menggunakan uji One-way Annova menunjukkan bahwapemberian ekstrak lidah buaya tidak berpengaruh nyata terhadap semua perlakuan baik pada minggu pertama, kedua, dan ketiga. Dimana pada semua perlakuan dari minggu pertama, kedua dan ketiga mengalami penurunan serta kenaikan jumlah hemoglobin. Penurunan tertinggi terjadi pada perlakuan P0 (kontrol) pada minggu kedua setelah diuji tantang dengan jumlah hemoglobin dari 6,33 menjadi 5,47. Sedangkan kenaikan jumlah hemoglobin tertinggi terjadi pada minggu ketiga pada perlakuan P5 setalah 
Jurnal Perikanan (2020) Volume 10. No. $1: 55-69$

DOI : https://doi.org/10.29303/jp.v10i1.175

diuji tantang dan diberi perlakuan

(Gambar 3).

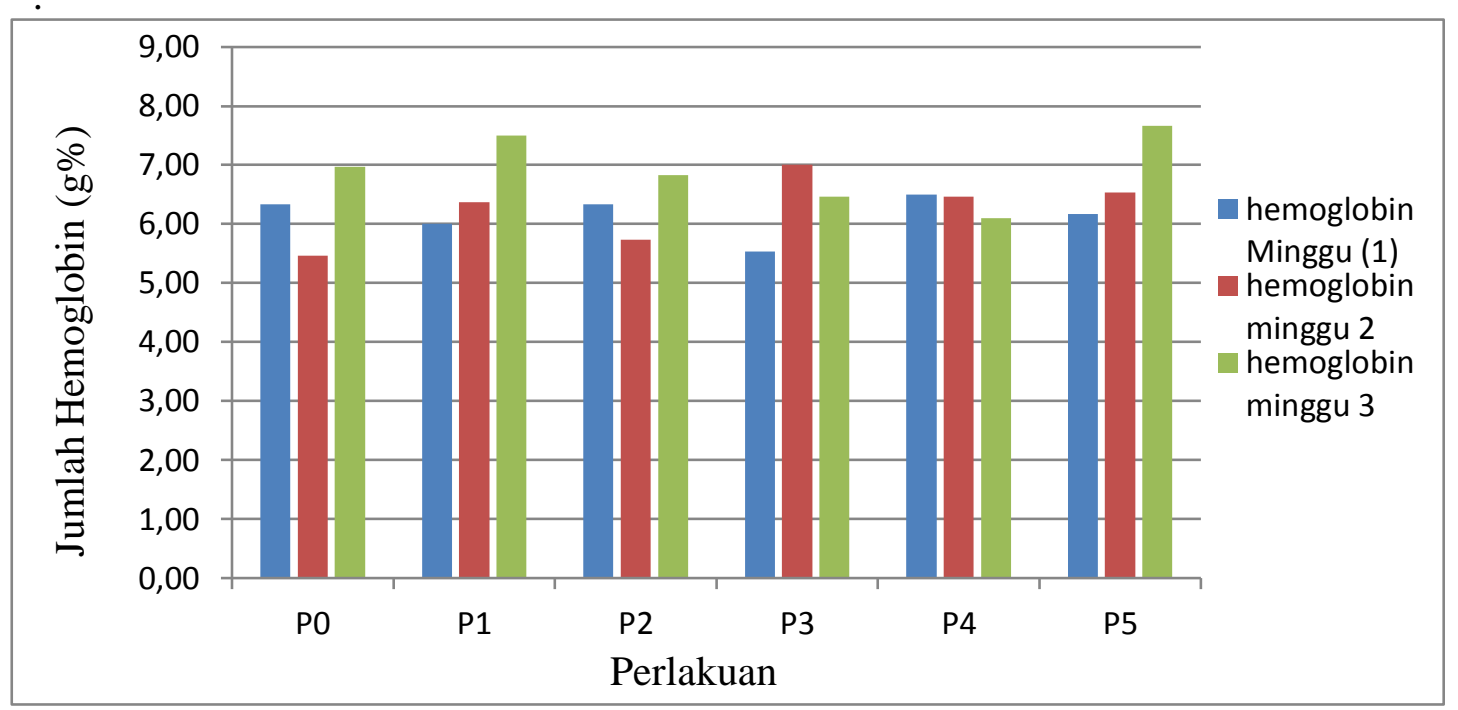

Gambar 3. Grafik Pengamatan Hemoglobin Ikan Kakap Putih

Hemoglobin merupakan bagian dari eritrosit dimana fungsi hemoglobin sebagai pengangkut oksigen dan karbondioksida. Moyle dan Cech (1998) dalam Vonti (2008) menjelaskan fungsi hemoglobin sebagai transport oksigen dan karbondioksida. Gambar 8 menunjukkan bahwa setiap perlakuan mengalami penurunan dan kenaikan jumlah hemoglobin, naik turunnya jumlah hemoglobin disebabkan karena infeksi dari bakteri Vibrio pada hewan uji. Rataan kadar hemoglobin sebelum diuji tantang pada perlakuan kontrol sebesar 6,33 g\% perlakuan P1 sebesar 6,00 g\%, $\mathrm{P} 2$ sebesar 6,33 g\%, P3 sebesar 5,53 g\%, P4 sebesar 6,50 g\%, dan P5 sebesar 6,17 $\mathrm{g} \%$.

Dari semua perlakuan, perlakuan kontrol merupakan perlakuan yang mengalami penurunan jumlah hemoglobin paling tinggi, sedangkan kadar hemoglobin tertinggi didapatkan pada perlakuan P5 pada minggu ketiga setelah diuji tantang. Jumlah hemoglobin dari semua perlakuan berkisar antara 5,47-7,67 g\%.Lagler et al. (1977) dalam Setiawati (2017) menyatakan bahwa jumlah hemoglobin umumnya berbanding lurus dengan jumlah eritrosit. Rendahnya konsentrasi hemoglobin menunjukkan terjadinya anemia dalam tubuh ikan. Ikan yang menderita anemia memiliki konsentrasi hemoglobin yang rendah akibat penurunan jumlah eritrosit. Hardi et al. (2011) melaporkan kadar hemoglobin dalam darah berkaitan dengan osmolaritas plasma darah.Royan (2014) mengemukakan bahwa rendahnya kadar hemoglobin berdampak pada jumlah oksigen yang rendah didalam darah. Pendapat serupa juga dikemukakan oleh Listiyanti (2011) dalam Matofani (2013), yang menyebutkan bahwa kadar hemoglobin setelah uji tantang mengalami penurunan. Hal ini disebabkan karena terjadinya penurunan jumlah eritrosit. 
Jurnal Perikanan (2020) Volume 10. No. 1 : 55-69

DOI : https://doi.org/10.29303/jp.v10i1.175

\section{Diferensial leukosit}

Pengamatan diferensial leukosit diantaranya yaitu: Limfosit, monosit, dan neutrofil. Semua pengamatan dilakukan sebelum dan sesudah dilakukan uji tantang.Dari hasil statistik uji One-way Annova menunjukkan bahwa ada pengaruh nyata terhadap peningkatan jumlah monosit, tetapi tidak berbeda nyata terhadap jumlah limfosit dan neutrofil antar semua perlakuan. Setelah uji Anova maka dilakukan uji lanjut tukey untuk mengetahui perlakuan yang terbaik.

Hasil pengamatan total limfosit pada pengamatan minggu ketiga menunjukkan bahwa setiap perlakuan mengalami peningkatan. Akan tetapi, setelah dilakukan analisis uji One-way Annova menunjukkan bahwa penambahan ekstrak lidah buaya tidak berpengaruh nyata terhadap setiap perlakuan.Jumlah limfosit pada perlakuan P0 sebanyak 82,67\%, perlakuan P1 sebanyak83\%, perlakuan P2 sebanyak 80,33\%, perlakuan P3 sebanyak $81 \%$, perlakuan P4 sebanyak $79 \%$, dan total perlakuan P5 sebanyak $84,33 \%$. Jumlah limfosit ini masih dalam kisaran normal, hal ini dapat diperkuat oleh Blaxhall (1972) dalam Hardi (2005) yang mengatakan bahwa nilai limfosit pada ikan normal berkisar antara 71,12 $82,88 \%$ dari total leukosit.Hasil ini menunjukkan bahwa perlakuan yang diberi ekstrak lidah buaya dengan konsentrasi yang berbedatidak memberikan pengaruh terhadap peningkatan jumlah limfosit.

Peningkatan jumlah sel limfosit pada tubuh ikan menandakan sistem imun ikan semakin meningkat. Hal ini sesuai dengan pernyataan Hartika et al. (2014) bahwa peningkatan limfosit yang dihasilkan berperan cukup besar terhadap peningkatan respon imun ataupun ketahanan tubuh ikan terhadap serangan penyakit dan infeksi. Limfosit tidak bersifat fagositik namun memegang peranan penting dalam pembentukan antibodi.

Selain itu, berdasarkan hasil penelitian diketahui bahwa sel limfosit memiliki presentasi tertinggi dibandingkan dengan sel lain. Hal ini berhubungan dengan fungsi sel limfosit sebagai penghasil zat kekebalan tubuh, pernyataan ini sesuai dengan pendapat Rustikawati (2012) dalam Muhammad (2016) bahwa jumlah sel limfosit pada ikan lebih banyak dibandingkan dengan sel neutrofil maupun monosit. Setiawan et al. (2012) menyatakan bahwa proporsi yang tinggi disebabkan oleh fungsinya dalam menyediakan zat kebal tubuh. Limfosit tersebut akan membesar yang kemudian membentuk antibodi spesifik sesuai dengan antigen memberikan rangsangan.

Limfosit merupakan jenis sel leukosit yang paling dominan di dalam populasi leukosit pada ikan. Peningkatan persentase limfosit merupakan refleksi keberhasilan sistem imunitas ikan dalam mengembangkan respon imunitas seluler (non spesifik) sebagai pemicu untuk respon kekebalan. Pada dasarnya sel limfosit terdiri dari dua populasi sel B dan sel T. Sel B mempunyai kemampuan untuk bertransformasi menjadi sel plasma yaitu sel yang memproduksi antibodi. Sedangkan sel $\mathrm{T}$ sangat berperan dalam kekebalan perantara sel $\mathrm{T}$ (sel $\mathrm{T}$ sitotoksik) dan mengontrol respon imun (sel T supresor). Menurut Tizard (1987) dalam Rustikawati (2012), imunostimulan dapat meningkatkan limfosit sel $\mathrm{T}$ yang terdapat dalam peredaran darah hewan tingkat tinggi yang berperan penting sebagai imunitas 
seluller yang penting untuk memproteksi tubuh dari bakteri dan virus intraseluler.

Limfosit yang teraktivasi akan berdiferensiasi dari sel kognitif yang mengenal antigen menjadi sel efektor yang berfungsi menyingkirkan antigen menjadi sel efektor yang berfungsi menyingkirkan antigen. Setelah terjadi pengikatan antigen dengan reseptor antigen sel limfosit, maka sel limfosit akan membelah dan berdiferensiasi menjadi sel efektor dan sel memori. Sel T-sitolitik yang berdifferensiasi mempunyai granula sitoplasmik lebih banyak yang mengandung protein yang berfungsi melisiskan sasaran.Limfosit B berdifferensiasi menjadi sel plasma yang memproduksi antibodi.Limfosit yang terbentuk oleh imunostimulan membantu dalam mensintesa antibodi dan memfagosit bakteri (Moyle dan Cech, 2004 dalam Rustikawati, 2012).

Hasil pengamatan jumlah monosit dari semua perlakuan selama penelitian yaitu berkisar antara 9,33-15,33 \%. Jumlah monosit yang didapatkan pada penelitian ini masih diatas kisaran normal untuk ikan kakap putih. Hal ini dapat diperkuat oleh Hardi (2006) bahwa jumlah sel monosit normal untuk ikan kakap yaitu sebanyak $100 \%$ dan $10 \%$ diatas kisaran normal sedangkan $0 \%$ di bawah kisaran normal. Hasil analisis statistik uji One-way Annova menunjukkan bahwa penginfeksian dan pemberian ekstrak lidah buaya memberikan pengaruh terhadap peningkatan jumlah sel monosit pada ikan kakap putih. Hal ini dikarenakan pada saat terjadi infeksi benda asing pada ikan maka monosit akan bergerak dengan cepat meninggalkan pembuluh dan menuju daerah yang diinfeksi.

Presentasi sel monosit ikan kakap putih relatif rendah dibandingkan dengan ikan air tawar. Sedangkan monosit sebagai salah satu bagian sistem imun merupakan sel makrofag yang berperan dalam memfagosit partikel asing yang masuk kedalam tubuh yang dapat menyebabkan infeksi, sehingga tubuh ikan tidak melakukan produksi sel monosit. Hal ini sesuai dengan pernyataan Utami et al.(2013) bahwa rendahnya proporsi monosit berkaitan dengan fungsi monosit itu sendiri yaitu sebagai makrofag, dimana monosit tidak terlalu banyak dibutuhkan untuk memfagosit, dikarenakan belum ada infeksi yang masuk kedalam tubuh yang merangsang produksi monosit.

Monosit berperan sebagai makrofag dan banyak dijumpai pada daerah peradangan atau infeksi. Monosit bersama makrofag jaringan setempat akan memfagositosis sisa-sisa jaringan dan agen penyebab penyakit. Persentase monosit di dalam darah ikan sekitar $0,1 \%$ dari total populasi leukosit yang bersirkulasi. Pernyataan ini didukung oleh pernyataan Rustikawati (2012), bahwa jumlah sel limfosit paling banyak, kemudian sel neutrofil dan jumlah yang paling sedikit adalah sel monosit.

Sel neutrofil dari sistem imun yang berfungsi dalam memfagosit infeksi penyakit yang disebabkan oleh serangan suatu mikrorganisme atau serangan benda asing lainnya. Menurut Davis et al. (2008) neutrophil atau heterophis adalah fagosit dalam leukosit, dan berkembangbiak dalam menanggapi infeksi, peradangan dan stres.

Hasil pengamatan sel neutrofil yaitu berkisar antar $8-12 \%$ dari total leukosit, berdasarkan hasil statistik ujiOne-way Annova diketahui bahwa tidak ada pengaruh yang berbeda nyata terhadap jumlah sel neutrofil pada setiap perlakuan. Hal ini menunjukkan bahwa 
penginfeksian bakteri Vibrio sp. dan pemberian ekstrak lidah buaya tidak memberikan pengaruh terhadap jumlah sel neutrofil. Berdasarkan pendapat Rustikawati (2013), jumlah neutrofil ikan normal berkisar 20-25\%. Penurunan jumlah neutrofil dikarenakan penginfeksian dari bakteri patogen sudah mulai berkurang, hal ini dilihat dari luka dan infeksi ikan yang sudah berkurang.

Hartika et al. (2014) juga mengemukakan bahwa presentasi neutrofil yang rendah menunjukkan tidak adanya serangan mikroorganisme sehingga neutrofil belum banyak diproduksi oleh tubuh ikan. Sedangkan Mahasri et al. (2011) melaporkan bahwa berdasarkan fungsinya neutrofil tidak terlalu berperan dalam proses pertahanan tubuh terhadap lingkungan sehingga tubuh ikan tidak melakukan produksi sel neutrofil dan presentasinya dalam darah menjadi berkurang.

\section{Tingkat Kelangsungan Hidup}

Hasil analisis statistik uji One-way Annovamenunjukkan bahwa ikan yang diinfeksi bakteri Vibrio sp. dengan pemberian ekstrak lidah buaya memberikan pengaruh yang signifikan ( $\mathrm{P}<0,05$ ) terhadap nilai Survival rate pada ikan kakap putih.Selanjutnya dilakukan uji lanjut tukey untuk mengetahui apakah ada perbedaan nyata antar semua perlakuan. Hasil pengamatan dapat dilihat pada Gambar 4.

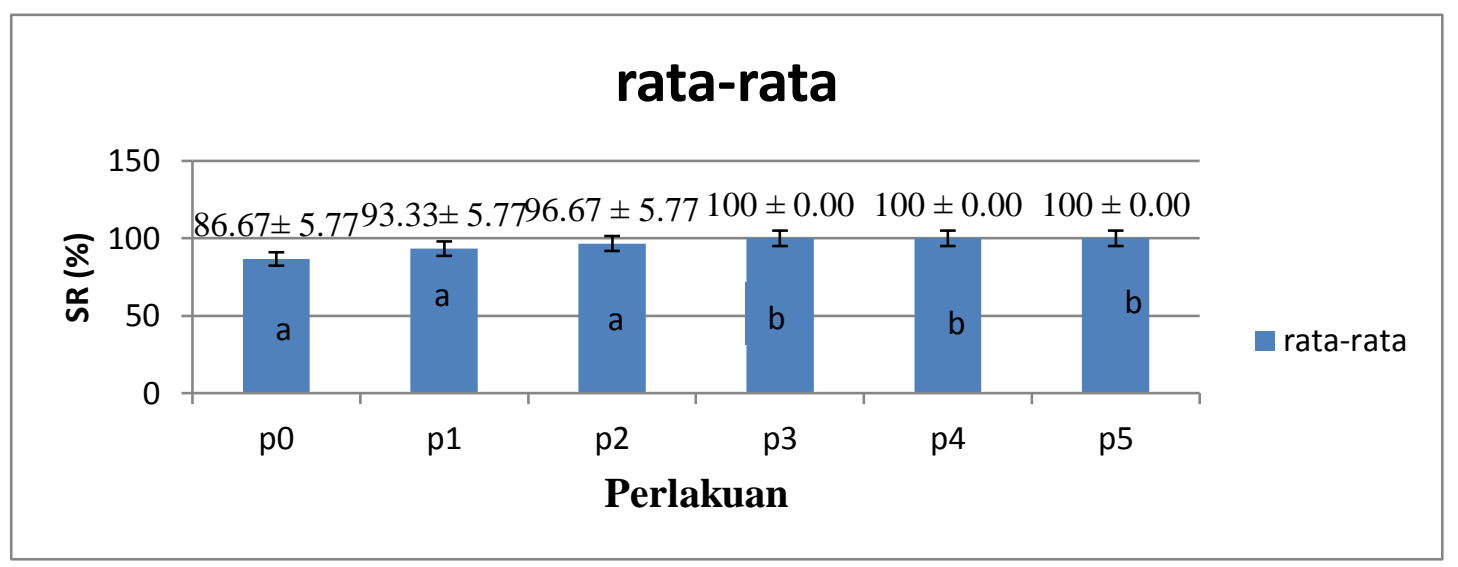

Gambar 4. Grafik Pengamatan Tingkat Kelangsungan Hidup Ikan Kakap Putih

Berdasarkan hasil uji lanjut tukey diketahui bahwa P0 tidak beda nyata dengan P1 dan P2, tetapi berbeda nyata dengan P3, P4, dan P5. Sedangkan P1 dan P2 tidak berbeda nyata dengaan P3, P4, dan P5. Hal ini karena pemberian ekstrak lidah buaya dapat meningkatkan daya tahan tubuh ikan terhadap serangan bakteri Vibrio sp. Hasil pengamatan menunjukkan bahwa survival rate tertinggi didapatkan pada perlakuan $\mathrm{P} 3$, P4 dan P5 dengan tingkat kelangsungan hidup (100\%), diikuti dengan perlakuan P2 dengan tingkat kelangsungan hidup sebesar 96,67\%, sedangkan pada perlakuan P1 berada pada tingkat kelangsungan hidup ketiga dengan jumlah 93,33\% dan tingkat kelangsungan hidup terendah berada pada perlakuan P0 dengan tingkat kelangsungan hidup sebesar $86,67 \%$. Tinggi rendahnya tingkat kelangsungan hidup dipengaruhi oleh jumlah eksrak lidah buaya yang digunakan, semakin banyak konsentrasi 
lidah buaya yang digunakan maka menghasilkan tingkat kelangsungan hidup yang semakin tinggi. Akan tetapi, penggunaan dosis ekstrak lidah buaya dengan jumlah yang terlalu tinggi (40$50 \%$ ) tidak berbeda nyata dengan pemberian $30 \%$. Hal ini menunjukkan bahwa penggunaan dosis $40-50 \%$ lebih baik menggunakan dosis $30 \%$ jika dilihat dari segi jumlah dan hasil yang sama. Jadi direkomendasikan bahwa, penggunaan ekstrak lidah buaya 30\% telah memberikan tingkat kelangsungan hidup $100 \%$.

Prasetio (2017) mengemukakan bahwa lidah buaya mengandung benzenadikarboxylic danoktadecenoic sebagai anti bakteri yang berfungsi sebagai penyembuh luka pada ikan sehingga keberadaan bakteri pada tubuh ikan kakap putih dapat ditekan sehingga keberadaannya berkurang.

Tingkat kelangsungan hidup ikan kakap putih juga dipengaruhi oleh kondisi lingkungan tempat ikan dipelihara. Kondisi lingkunganyang baik dan sesuaimendukung kehidupan yang baik pula untuk organisme yang dipelihara dikarenakan kondisi lingkungan yang baik akan berdampak pada tingkat konsumsi pakan yang baik pula sehingga pakan dapat dicerna dan ikan mendapatkan kelangsungan hidup yang tinggi. Kondisi lingkungan yang dimaksud seperti keberadaan oksigen terlarut yang sesuai dengan yang diperuntuhkan biota yang dipelihara, $\mathrm{pH}$ yang normal, suhu yang tepat serta salinitas yang tepat pula. Jika kondisi lingkungan tersebut baik maka akan mendukung kegiatan pemeliharaan ikan sehingga kelangsungan hidup pun tinggi. Hal ini sesuai dengan pernyataan Ghufron dan Kordi (2014) rendahnya tingkat kelangsungan hidup ikan kakap putih pada perlakuan kontrol, didugakarena pakan yang diberikan tidak ditambahkan dengan ekstrak lidah buaya, sehingga manfaat ekstrak lidah buayayang dapat meningkatkan sistem imun tidak terjadi pada perlakuan kontrol. Sehingga ikan pada perlakuan kontrol lebih rentan terhadap serangan penyakit sebagai akibatnya ikan mudah menjadi stres.

Selain penggunaan ekstrak lidah buaya yangsesuai, tingkat kelangsungan hidup dan tingkatpencegahan yang tinggi juga ditunjang oleh pengontrolankualitas air yang baik,hal ini sesuai dengan pendapat Boyd (1998), bahwa lingkungan yang baik akan meningkatkandaya tahan ikan, sedangkan lingkungan yang kurang baikakan menyebabkan ikan mudah stres dan menurunkan daya tahan terhadap serangan bakteri.

\section{KESIMPULAN}

Adapun kesimpulan yang dapat ditarik dari penelitian ini adalah sebagai berikut:

1. Pemberian ekstrak lidah buaya dengan cara dicampur kedalam pakan ikan kakap putih tidak memberikan pengaruh yang signifikan terhadap penambahan jumlah sel derah merah (eritrosit), kadar hemoglobin, dan diferensial leukosit (limfosit, neutrofil).

2. Dosis ektrak lidah buaya terbaik ditujukkan pada total sel darah putih (leukosit) pada perlakuan 5 minggu ke tiga dengan total sel darah putih (leukosit) sebanyak $35.700 \mathrm{sel} / \mathrm{mm}^{3}$. Sedangkan dosis ekstrak lidah buaya terbaik didapatkan pada dosis 40, 60, $100 \mathrm{ml} / 500$ gram pakan pada perlakuan 3, 4 dan 5 memberikan tingkat kelangsungan hidup $100 \%$. 
Jurnal Perikanan (2020) Volume 10. No. 1 : 55-69

DOI : https://doi.org/10.29303/jp.v10i1.175

DAFTAR PUSTAKA

Affandi, R.dan U. Tang. 2002.Fisiologi Hewan Air. Riau (ID): University Riau Press: 159 hlm.

Arianti. 2012.Potensi Ekstrak Lidah Buaya (Aloe Vera) sebagai Imunostimulan untuk Meningkatkan Sistem Kekebalan Non Spesifik pada Ikan Patin (Pangasius Hypophthalamus). Skripsi. Program Studi Budidaya Perairan, Fakultas Perikanan dan Ilmu Kelautan, Universitas Muhammadiyah Pontianak. Pontianak: $75 \mathrm{hlm}$.

Austin, B. dan D.A.Austin. 2007. Bacterial Fish Pathogen Disease of Farmed and Wild Fish. Springer Inc. London: $456 \mathrm{hlm}$.

Anderson, D.P. dan A.K. Siwicki. 1993. Basic haematologi and serology for fish health programs. Paper present in second symposium on diseases in Asian Aguaculture "Aquatic Animal Health and the Environment" Phuket. Asian Fisheries Society. Thailand:17 hlm. Blaxhall, P.C dan K.W. Daisley. 1972. Routine Haemotological Methods For Use With Fish Blood. J Fish Biol. Vol. 5 (2): 577-581.

Dosim, E.H. dan Agustina. 2013. Efek Penginjeksian Produk Intraseluler (ICP) dan Ekstraseluler (ECP) Bakteri Pseudomonas sp. terhadap Gambaran Darah Ikan Nila (Oreochromis niloticus). Jurnal Ilmu Kelautan dan Perikanan Tropis. Vol. 19 (1). 84-86.

Davis, A.K., D.L. Maney dan J.C. Maerz. 2008. ReviewThe Use Of Leukocyte Profiles to For Ecologists. Functional Ecology. Vol. 22 (5): 722-760.
Ellis, A.E. 1988. General Principle of Fish Vaccination. Academic Press. London: $132 \mathrm{hlm}$.

Faridah, N. 2010. Efektivitas Ekstrak Lidah Buaya (Aloe vera) dalam Pakan sebagai Imunostimulan untuk Mencegah Infeksi Aeromonas hydophila pada Ikan Lele dumbo Clariassp. Skripsi. Departemen Budidaya Perairan, Fakultas Perikanan dan Ilmu Kelautan, Institut Pertanian Bogor. Bogor: 14 hlm.

FAO. 2004. Fish Marketing and Credit In Viet Nam. In FAO Fishering Technical Paper ID: 167171. Fishering and Aquaculture Departement. Rome.

Hardi, E.H. 2005. Kesehatan Ikan dalam Keramba Pembesaran di Desa Selangan. Jurnal Akuakultur Rawa Indonesia. Vol. 3 (2): 46-54.

Hartika, R, Mustahal dan A.N. Putra. 2014. Gambaran Darah Ikan Nila (Oreochromis niloticus) dengan Penambahan Dosis Probiotik yang Berbeda dalam Pakan. Jurnal Periakanan dan Kelautan. Vol. 4 (1) : 259-267.

Ilham. 2018. Profil Darah Ikan Mas (Cyprinus carpio) yang Diinfeksi Pseudomonas fluorescens melalui Pemberian Ekstrak Sargassum sp. Skripsi. Prodi Budidaya Perairan Fakultas Pertanian Universitas Mataram. Mataram: $39 \mathrm{hlm}$.

Jatnika, A.dan Saptoningsih. 2009.Meraup Laba dari Lidah Buaya.Agro Media Pustaka. Jakarta: 120 hlm.

Kamaluddin. 2011. Efektivitas Ekstrak Lidah Buaya (Aloe Vera)untuk Pengobatan Infeksi Bakteri Aeromonas hydrophila pada Ikan Lele dumbo Clarias sp. Melalui 
Jurnal Perikanan (2020) Volume 10. No. 1 : 55-69

DOI : https://doi.org/10.29303/jp.v10i1.175

Pakan. Skripsi.Departemen Budidaya Perairan, Fakultas Perikanan dan Ilmu Kelautan, Institut Pertanian Bogor. Bogor: 54 hlm.

Kordi,M.G.H. 2013. Budidaya Ikan Air Konsumsi di Air Tawar.Lily Publisher.Yogyakarta: $356 \mathrm{hlm}$.

Mahasri, G., P.Widyastuti dan L.Sulmatiwi. 2011. Gambaran Leukosit Darah Ikan Koi (Caprynus carpio) yang Terinfeksi Ichthypohthirius multifillis pada Derajat Infestasi yang Berbeda dengan Metode Kohabitasi. Jurnal Ilmiah Perikanan dan Kelautan.Vol. 3 (1) : 91-96.

Prasetio, E., H. HastiadidanN.C. Wahyu. 2017. Pengaruh Serbuk Lidah Buaya (Aloe vera) terhadap Patogenitas Ikan Jelawat (Leptobarbus hoevnii) yang Diuji Tantang Bakteri Aeromonas hydrophilla. Jurnal Ruaya Vol. 5 (1): 11-22.

Puspasari, N. 2010.Efektivitas Ekstrak Rumput Laut Gracilaria verrucosasebagai Imunostimulanuntuk Pencegahan Infeksi Bakteri Aeromonas hydrophilapada Ikan Lele dumbo Clarias sp. Skripsi. Fakultas Perikanan dan Ilmu Kelautan,
Institut Pertanian Bogor. Bogor: 32 hlm.

Sani, A.2014. Pengaruh Penambahan Fukoidan pada Pakan terhadap Respon Imun Non Spesifik Induk Ikan Nila (Oreochromis niloticus).Jurnal Galung Tropika. Vol. 3 (3): 159-170.

Susandi, F., Mulyana dan Rosmawati. 2017. Peningkatan Imunitas Benih Ikan Gurame (Osphronemus gourami Lac.)terhadap Aeromonas hydrophila menggunakan Rosella (Hibiscus sabdariffa L.). Jurnal Mina Sains. Vol. 3 (2).1-13.

Sari, W.P., Agustono dan D. Cahyoko. 2009. Pemberian Pakan dengan Energi yang Berbeda terhadap Pertumbuhan Benih ikan Kerapu Tikus (Cromileptes altivekis). Jurnal Penelitian Budidaya Perikanan Univresitas Hang tuah. Vol. 3 (2): 218.

Utami, D.T., S.B. Prayitno, S. Hastuti dan A. Santika. 2013.Gambaran Parameter Hematologis Pada Ikan Nila (Oreochromis Niloticus) yang diberi Vaksin DNA Streptococcus Iniae dengan Dosis yang Berbeda. Journal of Aquaculture Management and Technology. Vol. 2. (4):7-20. 